\title{
Empowerment Communications as a New Perspective in the Empowerment of Coastal Communities of Pase Raya
} (Bireuen District, Lhokseumawe City and Aceh Utara District)

\author{
Mirodiyatun Resi Nuridayati ${ }^{1}$, Kamaruddin Hasan ${ }^{2 *}$
}

\author{
${ }^{1}$ North Aceh District Government Social Service \\ 2 Department of Communication Studies, Faculty of Social and Political Sciences, University of Malikussaleh \\ ${ }^{*}$ Corresponding author. Email: kamaruddin@unimal.ac.id
}

\begin{abstract}
This study aims to capture and understand empowerment communication as a new perspective in empowering coastal communities with the spirit of voicing the voiceless, in revealing social changes that occur in the development process as a description of the empowerment of coastal communities in communicating seen from the perspective of communicative action theory, people centered development, local wisdom and social capital. Whereas the presence of development communication is basically intended to contribute to the development process, especially in order to accelerate the diffusion process of innovation. The diffusion of innovation in development is an effort to meet the demands of modernization. Therefore, development is often equated with the term modernization. One indicator of modernization is the presence of communication technology that is very fast developing. Communication technology that was created to facilitate human work in the end was not able to place humans as subjects, but instead became the object of technology. The helplessness of individual humans when dealing with communication technology is a picture of the failure of the development process and human-centered social change. Communities are often powerless to stem the hegemony of communication technology. This research is a using paradigm qualitative interpretative approach. Data was collected through in-depth interviews, observation, and documentation. The results of this study include' Changes in people's or coastal communities mindsets are able to bring them to a pattern of behavior that is different from before. In the process of this change it can be seen that in the community there is a process of self-help to get out of stigma as a poor society. Communicative actions of the community based on four claims according to the communicative action theory of Habermas in the empowerment process show the empowerment of the coastal community in communicating that moves them in a living condition based on the existence of mutually agreed upon values, norms and social capital. The functioning of social groups into public spaces for the community to communicate and express, thus fostering emancipation and solidarity among the coastal community. Social groups are the most effective forum for empowerment at the coastal community level that enables individuals to organize themselves in these groups or collective self-empowerment so that a dialogical encounter occurs that fosters and strengthens awareness of communication and group solidarity.
\end{abstract}

Keywords: Communication Empowerment, Development, Communicative Action Theory, Social Ccapital, Costal Community and People Centered Development

\section{INTRODUCTION}

Coastal communities are still identified and stigmatized as poor, slum, marginalized, underdeveloped, low education, and are often perceived as a type of society that is resistant, stubborn, rude, difficult to change weak in literacy, and powerless in stemming the hegemony of communication technology. Almost all unpleasant things are attached to coastal 
communities. Although in fact, not everything is true. It is still limited to perception, stereotype and stigma.

This is an irony, on the one hand, where Pase Raya is an area with enormous potential for coastal and marine resources. It seems that the extraordinary potential has not been able to guarantee the creation of socio-economic welfare for the coastal communities, especially fishermen, fishermen laborers and pond farmer laborers. Government and private programs which are actually designed to make fishermen prosperous, find challenges in their implementation.

The coflicts between the government and the community often occur because of differences in understanding, interests, and rules. This condition becomes a warning for the Government, Higher Education, Non-Governmental Organizations, Opinion Leaders, regional, national and international companies and the private sector in empowering the community to improve the welfare of coastal communities.

Indeed, coastal community resistance in the empowerment process still often appears, one of which is due to mutual suspicion among components of coastal communities about the interests behind empowerment efforts. Especially from coastal community groups who are not the main target of the empowerment program.

Science of communication plays a very important role in the formation of communicative action in coastal communities by the use of capital and local wisdom. Empowerment communication becomes a new perspective for coastal communities as development communication with the spirit of voicing the voiceless.

The problem is how to find a solution to empower coastal communities with the perspective of empowerment communication and communicative action. How to invite all coastal communities to participate in all stages of development and how to maximize their potentials based on local wisdom.

This study aims: 1. To reveal how empowerment communication and communicative action play a role in the empowerment process and social change in the coastal communities of Pase Raya based on local wisdom. 2. To describe the participation of coastal communities in the development process as an illustration of community empowerment in communicating. 3. To describe the potentials and weaknesses of the Pase Raya coastal community in empowerment efforts. 4. Presenting views of Empowerment Communication and communicative action in the process of empowering coastal communities based on local wisdom.

The benefits of this research include: 1. As a scientific discourse on empowerment communication with new perspectives in empowering coastal communities based on local wisdom. 2. As a scientific discourse on communicative action in empowering coastal communities based on local wisdom. 3. As a form of participatory improvement efforts for coastal communities in every stage of its development. 4. Adding literature for academics in studying communication issues on empowerment, communicative action, participation, local wisdom, and social capital in coastal communities.

\section{METHODOLOGY}

This type of research is descriptive qualitative, which is able to capture various qualitative information with thorough and nuanced descriptions (Soetopo, 2006), to understand the phenomena experienced by research subjects such as behavior, perceptions, motivation, actions in a holistic manner, descriptions in the form of words and language, in a special context that is natural and by utilizing various scientific methods (Moleong, 2004).

The research strategy is a case study in coastal communities, because this research is focused on the target with one characteristic that is in one location (Yin, 1987). Creswell (1998) states that the focus of a case study is the specification of a case in an event, which includes individuals, cultural groups or a portrait of life. This type of research strategy is embedded (embedded case study) research, because the problems and research focus have been determined from the beginning (Soetopo, 2006).

Data collection was carried out using in-depth interviews, observation, focus group discussion (FGD), and documentation. Informants were selected using purposive technique and snowball sampling. Purposive sampling is used to select informants who are deemed to have sufficient information based on the research objectives, while snowball sampling is used to find data from informants who cannot be determined since the beginning of the study.

The data obtained were analyzed using an interactive analysis model. Miles and Haberman (1984), three components of analysis; data reduction, data presentation, and drawing conclusions. Activities on these three components are carried out in an interactive form with the data collection process as a cyclical process. The data were validated using triangulation of sources and methods.

\section{LITERATURE REVIEW}

In this study, several theories and concepts were used, including the concept of art in living together 
in coastal communities. Alexis de Tocqueville (1835), About social capital, is one of the important factors that can contribute to the economic development of coastal communities. Because of the network, norms, and trust in it. Social capital is one of the vital aspects so that they are able to get out of poverty and have resilience in facing various challenges that are increasingly complex as a result of an increasingly globalized world.

In the concepts and strategies of how coastal community-based development works, its success can be seen from the various capitals of the community, such as human capital (personal skills; education, knowledge, health, expertise and others); Natural resources capital (natural resources; water resources, marine waters, forests, minerals, etc.); Produced economic capital (development of economic and financial assets, as well as other assets, and the main thing is social capital which includes norms / values, trust / mutual trust / trust and networks.

World Bank (1998) defines social capital as something that refers to the institutional dimension, the relationships created and the norms that shape the quality and quantity of social relations in society. In general, social capital has three main elements, namely trust, norms and networks (Putnam, 1993: 20-22). James Coleman (1988) as the first sociologist to bring social capital into the mainstream of American social science, which was further popularized by Robert Putnam's studies between 1993, 1995, 2000. (Eko, 2003, 2).

The concept of community empowerment (Ife; 2008), development is basically raising human resources, opportunities, knowledge and skills to increase capacity in determining the future. This definition departs from the main concept, which is to provide broad opportunities for people to determine their own direction of life in their community. It takes the values of openness, equality, responsibility, opportunity, choice, participation, mutual benefit, reciprocity, and continuous learning (FCDL; Zubaedi, 2014). Tahoba (2011) states that community involvement in community development programs has an impact on differences in communication between people who participate and people who do not participate.

Chambers (1995) states that community empowerment is a concept of economic development that summarizes social values that reflect a new development paradigm, which is "people centered development, participatory, empowering, and sustainable".

Communicative action, Habermas (1984) refers to actions directed by mutually agreed norms based on mutual expectations between interacting subjects using symbols. Communication becomes the starting point in this theory, and praxis is the central concept.

For the Communicative Action Theory there are four claims, namely: (1) truth, namely agreement on the natural and objective world; (2) rightness, namely agreement on the implementation of norms in the social world; (3) claims of authenticity / honesty (sincerity), namely an agreement about the conformity between one's inner world and one's expression; and (4) comprehensibility claims, namely the ability to explain the above claims and reach agreement on them. Any effective communication must achieve the fourth claim of "communication competence" (Hardiman, 2009).

Participatory Development Communication and Modernization, the presence of development communication is basically intended to contribute to the development process, especially in order to accelerate the diffusion process of innovation. The diffusion of innovation in development is an effort to meet the demands of modernization. Thus, development is often equated with the term modernization. indicators of modernization include the presence of communication technology which is rapidly developing. Communication technology that was created to facilitate human work in the end was unable to place humans as subjects, but instead became technological objects. The helplessness of the human individual when dealing with communication technology is a reflection of the failure of the human-centered process of development and social change.

Next is empowerment communication, that changes in behavior and communicative actions of coastal communities are increasingly leading to community independence and creativity. Community communicative action reflects an increase in the ability of the community to communicate, both between individuals, individuals with groups, and between groups. With the increase in communication skills, people have become accustomed to networking so that they are more independent and creative. This is what is called empowerment communication, a communication process that humanizes people, is participative and gives voice to those who have been unable to speak (voicing the voiceless).

The phenomenon of change in coastal communities shows that empowerment communication is currently a new perspective in understanding development communication. Community initiation and participation characterize the communication process of empowerment in the development process which leads the community to a condition of a better quality of life. In empowerment communication, the existence of technology is placed as part of the community learning process, not a determining factor for social change. As 
stated by Habermas (Hardiman, 2009), technology and other objective factors can only change society if society integrates them into communicative actions which have their own logic.

Such empowerment communication is a participatory communication process (Mulyana, 2007). The communication model is convergent, which means trying to get a reciprocal understanding among communication participants in attention, understanding and needs. This convergent communication approach is very effective in community-based development planning. In addition, this approach will pave the way for the growth of creativity and community competence in communicating their ideas.

\section{RESULTS AND DISCUSSION}

The results of research and discussion can be conveyed several important points, including first; Regarding the basic life philosophy of the Coastal community, that the life of the coastal communities of Pase Raya (Bireun Regency, Lhokseumawe City and North Aceh) has an interesting side. The side that can make them survive in any difficult situation. Coastal communities are known for their strong resilience. They are still able to laugh at the reality of their life. Also to understand the mindset of the coastal community, one can understand the hadih maja as local wisdom that still survives. This is influenced by the foundation and philosophy of life. They still maintain Islamic-based hadih maja that lasts and lasts from generation to generation.

Hadih maja implemented in the daily life of coastal communities, such as "Tajak u glee tajak koh kayêe, tinggai peureudê teumpat lêuk kutro. Tajak u blang tajak koh padee, tinggai ukhê jeuneurang kêu subu tanoh. Tajak u laut ta mita êungkot, beêu tinggai karêung teumpat êungkot meu aneuk cuco". "Urêung meu goe ngen urêung meu laut, dua sam lakoe, yang peukêng nanggroe”. (Author's interpretation, 2020).

Second, related to the Coastal Community of Empowerment Communication and social capital, the existence of a new paradigm in social communication and development as a process of empowering coastal communities, is marked by the awareness that the social communication and development process must be based on the social capital of the local community in planning, implementing, and evaluate development. Coastal communities are not objects of development, but subjects of development, so the participation of coastal communities is a very important factor.

Communication is carried out in a convergent manner, communication interactions are carried out in a more democratic and participatory manner.
Communication activities are not activities of giving and receiving but are dialogical. The problem is, so far, the involvement of coastal communities is only seen in a narrow context, coastal communities are only seen as recipients of development innovation, without being involved in planning and decision-making and not developing their inner creative power and must accept decisions that have been taken by outsiders. . So as to create community dependence on other parties, helpless and independent.

Empowerment of coastal communities is an alternative paradigm of development with the aim of bringing coastal communities to empowerment and independence. To lead to community independence, efforts to achieve welfare are the main thing. A prosperous society will be able to cope with their daily needs, both material and non-material needs.

The essence of any development activity is a change in attitude to project oneself into other situations and that arena is consciously and planned to prepare itself to make changes to improve the quality of life in order to anticipate circumstances and changes that will occur in the future.

Good development is development based on the coastal community itself towards the expected conditions for improving the quality and welfare of life. Meanwhile, empowerment of coastal communities is an activity that requires a sustainable process, so that good communication is needed between the program initiator and the coastal community and among members of the coastal community.

Participatory communication is the main pillar in the process of achieving the goal of empowering coastal communities. It takes the active participation of all residents of coastal communities to realize the goals, hopes and aspirations of the desired changes. The participation of coastal communities greatly influences the formation of communicative actions in accordance with the characteristics of coastal communities.

In coastal communities, it shows that every pattern of relationships that occur is bound by trust to mutual understanding and shared values that bind group members to make the possibility of joint action being carried out efficiently and effectively.

Third, the lack of supervision and assistance of local government, the main statement that appears in the field is that coastal communities do not need rhetoric of "world maritime axis". "We need the presence of all out local governments to protect and safeguard fishery resources which are the foundation of our livelihoods".

Fourth, problems arise when the waters experience overfishing so that the catch or income 
obtained is fluctuating, uncertain, and decreasing from time to time. There are many fish thieves in Pase Raya waters using Thai and Malaysian flag fishing boats.

Local fishermen do not damage the marine ecosystem, catching environmentally friendly fish by not destroying coral reefs or killing or catching fish seeds, has long been practiced by local fishermen. They are subject to Panglima Laot who traditionally regulates fishing and when they are prohibited from going to sea.

Fifth, marine customary maps, customary institutions, the role of figures and local wisdom, the coastal communities of Pase Raya have rules of abstinence from going to sea, such as Friday, three days during Eid al-Fitr holidays, three days during Eid al Adha, three days during sea feast, every August 17, as well as a tsunami warning day or December 26th. If calculated, Acehnese fishermen take almost two months off from fishing a year, not including bad weather. The day of not going to sea is very important, because it gives the fish the opportunity to breed. Without realizing it, Acehnese fishermen have been carrying out environmentally friendly activities, not draining the sea greedily.

It takes local wisdom which is a form of knowledge, understanding, belief, or insight as well as customs, habits or ethics that guide people to behave and behave in life. Local wisdom is part of ethics and morality that helps people to answer moral questions about what to do, how to act, especially in the field of environmental management and coastal and marine resources in Aceh, especially Pase Raya.

Sixth, the existence of environmental problems in the coastal area of Pase Raya, field studies also show that community management and coastal areas must have at least three functions, namely disaster mitigation, regional economic development and ecosystem protection. It is hoped that the integration of these three functions will lead to an environmentally friendly sustainable development of communities and coastal areas.

Based on the results of the field, it shows that the environment in coastal areas is getting worse, if left unchecked, then an ecological emergency could occur. Various regulations, qanuns, and regulations governing the environment are still so easily violated. Damage to the coastal environment, such as mangrove or mangrove forests, is now shrinking, turned into new ponds without clear permits, even though mangrove forests are a source of livelihood for coastal communities.

Seventh, the strategic direction of coastal community development, to the extent possible labor fishermen, farm laborers, salt farmers and / or the vulnerable, marginalized, and poor can be fully involved in empowerment. Includes, empowerment of human resources (HR), utilize marine and fisheries resources optimally, efficiently and sustainably. Improving the quality of marine fishery products is one of the activities that is economical and has strategic value and is very prospective, given the increasing world demand for fishery products.

Optimization of communities and coastal areas can only be carried out if there is good cooperation from various sectors, including the government, especially local governments, customary institutions and coastal communities, private parties / companies / industries and universities. It needs to be implemented, the triple helix (synergy and unification of three groups consisting of academics/universities, business/entrepreneurs and government). As a cooperation scheme between university-government industry to solve community development problems and coastal areas.

Eighth, changing the mindset of coastal communities is believed to be able to lead them to a different behavior pattern than before. In this process of change, it can be seen that in society there is a self-help process to get out of the stigma of being a marginalized society.

The process of change that occurs in coastal communities is strongly supported by communicative actions based on mutually agreed norms, values and symbols. In this case, a way of communicating is needed that is able to generate the motivation for the community to move towards the ideals of change that are desired together. This communication is developed by community leaders and formal leaders in coastal communities, namely communicating using language that is easily understood by the community and in accordance with their character. From an empowering and participatory way of communicating, it has an impact on changing people's mindsets.

Ninth, communicative action of coastal communities can be seen from the four claims according to Habermas' theory of communicative action in the empowerment process. In their communicative actions, it shows the empowerment of the community in communicating which is able to move them to a living condition based on the values and norms that are mutually agreed upon.

The dominant form of communication that occurs in the dynamics of coastal community participation is interpersonal communication. When the activity has not started, the communication situation between them is relaxed and friendly. The active participation of citizens in formal situations reflects that they are citizens who have great respect for the forum. Citizens really know when they can communicate in a 
relaxed and humorous manner, and when they have to be serious but relaxed.

In this way, it can be said that coastal communities are well informed citizens, they almost never miss information about developments and activities that they should know and follow. The use of communication tools is currently very important as a medium of communication between individuals and groups. The influence of communication in social groups in coastal communities on changes in community behavior is quite large.

That formal communication cannot be separated from informal communication in the process of research and implementation of empowerment. Formal communication takes place after open access and to reinforce an activity objective. The failure of the informal communication process results in resistance, lack of support, suspicion, and even rejection. Formal communication is structured, focused, and there is symbolic interaction on behalf of the institutional status of the actors of the communication. Meanwhile, informal communication is unstructured, the dialogue process is freer or less rigid, which can last a long time, although the discussion may be unfocused. Interaction emphasizes intimacy or having an intense relationship.

In relation to social processes, communication becomes a way of carrying out social change. Communication plays a role in bridging differences in society because it is able to reattach the social system of society in an effort to make changes. In this case, communication will not be separated from its social context, meaning that the communication process will be colored by attitudes, behaviors, patterns, norms, and community institutions.

The functioning of social groups into public spaces for society as a community forum for communication and expression, thereby fostering emancipation and solidarity among the people. Social groups are the most effective medium for empowerment at the community level which enables individuals to organize themselves into these groups (collective selfempowerment) so that a dialogical encounter occurs that fosters and strengthens awareness of communication and group solidarity.

Tenth, empowerment communication, that changes in behavior and communicative actions of coastal communities are increasingly leading to community independence and creativity. With the increase in communication skills, people have become accustomed to networking so that they are more independent and creative. Empowerment communication, a communication process that humanizes humans, is participative and gives voice to those who have been unable to speak (voicing the voiceless)

The phenomenon of change in coastal communities shows that empowerment communication is currently a new perspective in understanding development communication. The initiation and participation of coastal communities becomes the hallmark of the empowerment communication process in the development process that leads the community to a better quality of life. In empowerment communication, the existence of technology is placed as part of the community learning process, not a determining factor for social change.

Empowerment communication; participatory communication process. The communication model is convergent, which means trying to get a reciprocal understanding among communication participants in attention, understanding and needs. This convergent communication approach is very effective in coastal community-based development planning. In addition, this approach will pave the way for the growth of creativity and competence of coastal communities in communicating their ideas.

\section{CONCLUSIONS \& SUGGESTION}

Conclusions and suggestions are as follows:

1. Changes in the mindset of coastal communities can lead them to different behavior patterns from before. There is a self-help process (helping oneself) to get out of the stigma of being a coastal community who is marginalized, poor, marginalized and others.

2. The communicative action of the community is based on the claim that living conditions are based on the values and norms that are mutually agreed upon.

3. The functioning of social groups into public spaces for coastal communities to communicate and express themselves, thereby fostering emancipation and solidarity among coastal communities. There is collective self-empowerment, resulting in a dialogical encounter that fosters and strengthens awareness of communication and group solidarity.

4. With empowerment communication, that changes in behavior and communicative actions of coastal communities are increasingly leading to community independence and creativity. Increasing communication skills, people become accustomed to networking so that they become more independent and creative. Empowerment communication, as a communication process that humanizes humans, is participative and gives voice to those who have been unable to speak (voicing the voiceless). 
5. it is necessary to have a strategic directhordtma empower coastal communities, meaning that as far as possible, labor fishermen, fish farming labor, salt farmers and / or those who are vulnerable, marginalized, and poor can be fully involved in empowerment. The existence of good cooperation from various sectors, the triple helix, namely the synergy and unification of three groups consisting of universities, entrepreneurs, the private sector and the government.

6. Sixth, it is necessary to strengthen marine customary institutions, local wisdom which is a form of knowledge, understanding, belief, or insight as well as customs, habits or ethics that guide people to behave and behave in life. Local wisdom is part of ethics and morality that helps people to answer moral questions about what to do, how to act, especially in the field of environmental management and coastal and marine resources in Pase Raya.

\section{REFERENCES}

Arif Satria, (2015), Pengantar Sosiologi Masyarakat, Yayasan Pustaka Obor Indonesia

Basrowi dan Sukidin. 2002. Metode Penelitian Perspektif Mikro: Grounded Theory, Fenomenologi, Etnometodologi, Etnografi, Dramaturgi, Interaksi Simbolik, Hermeneutic, Konstruksi Sosial, Analisis Wacana, dan Metodologi Reflektif. Surabaya: Insan Cendekia

Chambers, R. 1995. Poverty and Livelihoods: From Impoverishment to voiceless). Empowerment. New York: New York University Press

\section{DKP Aceh, (2016). Laporan Tahunan DKP}

Erny Poedjirahajoe, Prof. Dr. (2019) Ekosistem Mangrove Karakteristik Fungsi dan Dinamikanya Original, Gosyen Publiser Yogyakarta

Fukuyama F. 1995. Trust: The Sosial Virtues and the Creation of Prosperity. The Free Press. New York.

Field, John. 2010. Modal Sosial. Diterjemahkan oleh Nurhadi dari buku asli Social Capital (2003). Bantul DIY: Kreasi Wacana.

FAO (2014), Panduan Perikanan Skala Kecil.

Habermas, Jurgen. 2015. Ruang Publik. Sebuah Kajian Tentang Kategori Masyarakat Borjuis. enerjemah: Yudi Santoso dari judul asli The Structural Transformation of the Public Sphere: An Inquiry into a Category of Bourgeois Society. Bantul: Kreasi Wacana.

Habermas, Jurgen. 1984. The Theory of Communicative Action. Jilid 1. Boston: Beacon Press.
F. Budi. 2009. Menuju Masyarakat Komunikatif. Yogyakarta: Penerbit Kanisius.

Hardiman, F. Budi (editor). 2010. Ruang Publik. Yogyakarta: Penerbit Kanisius. Ife, Jim \& Tesoriero, Frank. 2008. Community Development: CommunityBased Altenatives in An Age of Globalisation. Australia: Pearson Education.

J. 2006, Social Capital (Menuju Keunggulan Budaya Manusia Indonesia), Jakarta, MR-United Press.

Hasan, Kamaruddin (2012) Laporan Final Mapping Sosial Budaya Bidang; Pengembangan Ekonomi dan Ekologi Masyarakat. Community Ekonomi Dan Ekologi Development. (Bersama Talisman Energi, PT.Ecotropica, Pusat kajian Sumber Daya Pesisir dan Kelautan IPB).

Ketentuan Peraturan Menteri Kelautan dan Perikanan Nomor 23 Tahun 2016 tentang Perencanaan Pengelolaan Wilayah Pesisir dan Pulau-Pulau Kecil.

Marwoto. 2012. Peran Modal Sosial Masyarakat dalam Pengelolaan Hutan Rakyat dan Perdagangan Kayu Rakyat (Kasus di Kecamatan Giriwoyo, Kabupaten Wonogiri. Sekolah Pasca Sarjana: Institut Pertanian Bogor.

Mulyana, Deddy. (2001). Metode Penelitian Kualitatif llmu Komunikasi. Cetakan pertama.Bandung: Remaja Rosdakarya.

Mardikanto,2010. Komunikasi Pembangunan. Acuan bagi Akademisi, Praktisi, dan Peminat

Komunikasi Pembangunan. Surakarta: Sebelas Maret University Press.

Miles, M.B. \& Huberman, A.M. 1984. Qualitative Data Analysis: A Sourcebook of New Methods. New York, n.y : Holt, Rinehart, and Winston.

Moleong, Lexy. J. 2004. Metodologi Penelitian Kualitatif. Bandung: Remaja Rosdakarya.

Mulyana, Deddy. 2007. Ilmu Komunikasi Suatu Pengantar. Bandung: PT. Remaja Rosdakarya.

Nurudin. 2004. Sistem Komunikasi Indonesia. Jakarta : Rajawali Pers.

Nadjib, Mochammad, lembaga Ilmu Pengetahuan Indonesia; Memahami Budaya Ekonomi Nelayan Sebagai Dasar Meningkatkan Pilar Ekonomi Pesisir, dikutip dari Rural Talks Ikhtiar Memahami Transformasi Sosial Ekonomi Masyarakat Desa, Indonesia Human right Committee for Social Justice (IHCS), hal 186

Putnam, R.D (1993). The prosperous community: Social capital and public life. The American Prospect. Vol. 4, no. $13 . \quad$ Tersedia pada http://prospect.org/article/prosperous-community-sosialcapitaland-public-life

Primack I, Richard B. 1998. Biologi konservasi. Yayasan Obor Indonesia. Jakarta 
Sahri Muhamad, MS, Dr, Ir. Prof, 2011, Pemberdayaan Masyarakat Pesisir: Model Kemitraan SocioEcocentrisme, keluaran hasil penelitian Hibah Penelitian Strategis Nasional Tahun 2009 - 2011

Sutoro, Eko. (2003) Modal sosial, Desentralisasi dan Demokrasi lokal. Makalah disajikan dalam Seminar Internasional IV "Dinamika Politik Lokal di Indonesia: Demokrasi dan Partisipasi”, Salatiga,

Sulaiman, Adhi Iman. 2013. Model Komunikasi Formal dan Informal dalam Proses Kegiatan Pemberdayaan Masyarakat. Jurnal Penelitian Komunikasi, Volume 16 No.2 Desember 2013, hlm. 173-188.

Setyowati, Yuli, (2019), Komunikasi Pemberdayaan Sebagai Perspektif Baru Pengembangan Pendidikan Komunikasi Pembangunan Di Indonesia, Jurnal Komunikasi Pembangunan (IPB), VOL. 17 NO. 2 (2019): JULI 2019

Tahoba. 2011. Strategi Komunikasi dalam Program Pengembangan Masyarakat (Community Development), kasus program Community Development pada Komunitas Adat Terkena Dampak Langsung proyek LNG Tangguh di Sekitar Teluk bintuni Kabupaten Teluk Bintuni Papua Barat. Proceeding. http://www.google.com/url?paparisa.unpatti.ac.id, diunduh 21 Januari 2015).

Yin, R.K. 1987. Case Study Research: Design and Methods. Beverly Hills, CA: Sage Publication.

Zubaedi. 2014. Pengembangan Masyarakat. Wacana \& Praktik. Jakarta: Kencana Prenadamedia Group.

Zulida, Nina Situmorang (2017) Kaji Ulang Konsep Modal Sosial Dalam Masyarakat Pluralis, Fakultas Psikologi Universitas Gunadarma, Jakarta.

\section{Other sources}

BPS Provinsi Aceh (2020)

BPS Kabupaten Aceh Utara (2020)

BPS Kabupaten Bireuen (2020)

BPS Kota Lhokseumawe (2020)

Qanun No.1 Tahun 2020 Tentang RZWP-2 K, Provinsi Aceh pada tanggal 17 April 2020 menerbitkan Perda/Qanun Aceh No. 1 Tahun 2020 tentang RZWP-3K Aceh Tahun 2020-2040. Qanun tersebut masuk dalam Lembaran Aceh Tahun 2020 No 1 dengan Nomor Register Qanun Aceh (1-39/2020).

Qanun Aceh Nomor 10 Tahun 2008 tentang Lembaga Adat

Qanun Aceh No 9 tahun 2008 tentang Pembinaan Kehidupan Adat dan Istiadat

Qanun Nomor 21 Tahun 2002 Tentang Pengelolaan Sumber Daya Alam

Rothstein, Bo. 2005. Sosial Traps and The Problem of Trust. Cambridge University Press

\section{UUD 1945}

Undang-undang No 11 Tahun 2006 Tentang Pemerintah Aceh

Undang-Undang Nomor 32 Tahun 2014 tentang Kelautan

Undang-undang No. 27/2007 tentang Pengelolaan Wilayah Pesisir dan Pulau-Pulau Kecil.

Undang-Undang Nomor 32 Tahun 2009 tentang Perlindungan dan Pengelolaan Lingkungan Hidup (UUPPLH)

World Bank. 1998. The Initiative on Defining Monitoring and Measuring Sosial Capital. Overview and Program Description. Sosial Development Family. Environmentally and Sosially sustainable Development Network

RPJMN (2020-2024)

RPJM (2017-2022), Program Aceh Hebat

RDED (1992). Rio Declaration on Environment and Development

WWF Indonesia, 2018, Kajian Spatial dapat akseshttps://www.wwf.id/publikasi/perayaan-parapenjaga-mangrove. 